\title{
Strand Displacement Amplification
}

National Cancer Institute

\section{Source}

National Cancer Institute. Strand Displacement Amplification. NCI Thesaurus. Code C92626.

An isothermal, in vitro nucleic acid amplification method that allows primer-directed amplification of a target sequence. It utilizes a primer that can be nicked to create a polymerase start site and a DNA polymerase that will displace a downstream strand as it tracks along the template. 